\title{
ELEMENTY RYTUAŁU PRZEJŚCIA W INNYM JURIJA MAMLEJEWA. PROLEGOMENA
}

\section{ELEMENTS OF THE RITE DE PASSAGE IN THE OTHER BY YURI MAMLEEV. PROLEGOMENA}

\author{
ANNA KATARZYNA PRZYBYSZ
}

\begin{abstract}
This article is an attempt to analyze the category of meeting between two main characters in The Other using a symbolic key. I try to explain the important role of such semiotic categories as threshold and mask in the process of becoming more aware about ourselves, which I interpret as part of the process of rite de passage.
\end{abstract}

Anna Katarzyna Przybysz, Uniwersytet im. Adama Mickiewicza w Poznaniu, Poznań - Polska, przybysz_anna@02.pl

Dzieła Jurija Mamlejewa utrzymane są w kluczu realizmu metafizycznego - takim mianem pisarz określa artystyczną dominantę konstruowania świata przedstawionego swych utworów. Celem obranej przez niego metody kreowania rzeczywistości artystycznej jest wnikliwe przedstawienie procesu „poszukiwania prawdziwego siebie"1. Autor skupia swą uwagę przede wszystkim na ukazaniu wewnętrznego życia bohaterów swych utworów oraz zmian $\mathrm{w}$ sposobie postrzegania przez nich świata i swego w nim miejsca. Otaczająca rzeczywistość pełni zaledwie rolę drugoplanową - akcent położony zostaje na wewnętrzne stany postaci. To ukazanie przeżyć, zmagań ze sobą oraz ze światem stanowi główny cel wypracowanej przez Mamlejewa poetyki. Z tego względu wydarzenia, do jakich dochodzi w powieściowym świecie, zostają mocno wyeksponowane pod kątem znaczeniowej nośności symboliki. Głębsze warstwy utworu (mityczne, magiczne, mistyczne) pozwalają na dostrzeżenie tego potencjału interpretacyjnego tekstu, który nie jest uchwytny z poziomu fabularnego odczytania jego treści.

Jednym z ciekawszych dzieł Mamlejewa, w którym mamy do czynienia $\mathrm{z}$ problemem zmagań bohaterów $\mathrm{z}$ własnym światem wewnętrznym,

1 Ф.А. П о н о м а р е в, Катарсические эффректы в творчестве Юрия Мамлеева, [w:] źródło elektroniczne: http://www.google.ru/url?sa=t\&rct=j\&q=\&esrc=s\&frm=1\& source=web\&cd=1\&ved=0CCkQFjAA\&url=http $\% 3 \mathrm{~A} \% 2 \mathrm{~F} \% 2 \mathrm{Fzar}-$ literature.ucoz.ru $\% 2 \mathrm{~F}$ didaktika_1\%2Fkatarsicheskie_ehffekty_v_tvorchestve_jurija_mamle.docx\&ei=E1bFUq WfNoHXtAbZ6oGoDg\&usg=AFQjCNFkr1mquVZJce4pr0lhyF_Np0wqpA\&bvm=bv.581 87178,d.Yms\&cad=rjt (14.10.2013). 
jest Inny. Powieść ta zasługuje na szczególną uwagę także dlatego, iż stanowi jeden z nielicznych przykładów w twórczości pisarza, w którym re zygnuje on (przynajmniej $\mathrm{w}$ znacznej części) $\mathrm{z}$ zastosowania infernalnej poetyki, będącej jedną $\mathrm{z}$ charakterystycznych cech jego dzieł. Autor Szatunow, słynący z epatowania czytelnika brutalnością, przemocą oraz skrajnym weryzmem, w omawianym utworze zaskakuje stosunkowo łagodnym tonem, w jakim utrzymana jest narracja. Wydaje się, że odejście od zwyczajowego języka opisu zdarzeń zorientowane jest na uwydatnienie samych treści, podejmowanych w Innym. Pozbawienie powieści elementów zaskakujących, szokujących, czy wręcz odrażających, będących dotychczas nieodłączną częścią warsztatu pisarskiego Mamlejewa (a dla wielu odbiorców stanowiących o atrakcyjności jego utworów), powoduje przesunięcie uwagi czytelnika z języka opowieści na samą opowieść. Właśnie dlatego celem niniejszego artykułu jest próba analizy jednego z wydarzeń, do jakiego dochodzi pomiędzy powieściowymi postaciami, z punktu widzenia symbolicznej nośności atrybutów w nim partycypujących.

Aby należycie odczytać wagę obecności poszczególnych elementów wystroju wnętrza, w którym bohaterowie zawarli znajomość, należy pokrótce zarysować kontekst, w jakim doszło do tego wydarzenia. Jedna z głównych bohaterek powieści, malarka Alona, zostaje porwana na zlecenie Trofima Borysycza Łochmatowa. Artystka zostaje przewieziona do jego podmoskiewskiej willi, aby tam spotkać się ze wspomnianym bandytą. Powodem, dla którego kryminalista zapragnął poznać dziewczynę, jest jej obraz zatytułowany Нездешние mbари ${ }^{2}$. Łochmatow rozpoznał swe oblicze w jednym z potworów na namalowanym przez nią obrazie i porażony przenikliwością artystki postanowił „zaprosić” ją do swojej rezydencji, aby dowiedzieć się, kim jest osoba, która potrafiła dostrzec "prawdziwą twarz" bandyty. To spotkanie, w perspektywie całościowego odczytania utworu, stanowi asumpt do reorganizacji życia bohaterki. W procesie tej przemiany wyraźnie dostrzegalne są elementy rytuału przejścia - obrzędu, który wiąże się z przełomowym momentem w życiu człowieka, a także $\mathrm{z}$ wkroczeniem przez niego w nowy, nieznany obszar (zarówno w sensie terytorialnym, jak i przenośnym, emocjonalnym) ${ }^{3}$, co niesie ze sobą znaczne zmiany. Na charakter

2 Ю.В. М а м л е е в, Другой, Щелково 2007, s. 107. Ponieważ powieść nie ukazała się dotychczas $\mathrm{w}$ polskim przekładzie, odwołania do tekstu podaję w języku oryginału. $\mathrm{W}$ dalszej części artykułu będę stosować skrócony zapis, podając w nawiasie literę „I" oraz, po przecinku, numer strony, np. (I, 107). Zapis ten pojawi się w tekście głównym.

${ }^{3}$ Te i pozostałe odniesienia do rytuału (obrzędu) przejścia opieram przede wszystkim na spostrzeżeniach Victora Turnera, który kontynuował tradycyjną wizję tego ujęcia, zaproponowaną przez francuskiego etnografa Arnolda van Geneppa. Zob. V. T u r $\mathrm{n}$ e $\mathrm{r}$, Betwixt and between: The liminal period in "rites of passage", [w:] W.A. L e s s a, E.Z. V o g t, Reader in Comparative Religion: An Anthropological Approach (4th Edition), New York 1979, s. 234-243. 
wspomnianego powyżej trzyetapowego rytuału składają się następujące fazy: faza wyłączenia (inaczej preliminalna lub separacji), polegająca na pozbawieniu jednostki statusu, odebraniu jej miejsca, bądź odseparowaniu jej od grupy; faza marginalna (inaczej liminalna, bądź okres przejściowy), podczas której jednostka nie ma określonego statusu, nie przynależy do żadnej ze społeczności, tkwi w stanie zawieszenia; oraz faza włączenia (inaczej postliminalna lub integracji), podczas której nadawany jest jej nowy status. Próba oglądu postaw bohaterki przed wizytą $w$ willi bandyty, podczas jej pobytu $\mathrm{w}$ rezydencji, a także po zawarciu znajomości $\mathrm{z}$ Trofimem Borysyczem pozwala na dostrzeżenie zmian $\mathrm{w}$ sposobie postępowania dziewczyny, sugerujących, iż można je odczytać jako swoistą realizację poszczególnych etapów wspomnianego obrzędu. Na taki kontekst "pracuje” przede wszystkim symboliczna warstwa utworu, uwydatniająca doniosłą rolę spotkania z Łochmatowem w życiu malarki.

Bohaterka nie wie, czego się spodziewać po mężczyźnie, który rozkazał ją porwać. Obawiając się najgorszego (przemocy, gwałtu lub pozbawienia życia), postanawia skorzystać z technik adwaita-wedanty ${ }^{4}$, których uczył ją jej narzeczony Wadim. Zamierzeniem dziewczyny jest chęć odseparowania się od własnego ciała. Malarka próbuje zdystansować się względem swej „materialnej powłoki” w przekonaniu, iż nie pełni ona konstytutywnej roli w kształtowaniu jej , ja". Osiągnięcie zamierzonego rezultatu wiązałoby się dla Alony z wkroczeniem w nowy etap życia, w którym ciało nie stanowiłoby ontycznego fundamentu podmiotowości. Tak więc porwanie dziewczyny, odseparowanie jej od otoczenia, a także podjęta przez nią próba zrezygnowania z własnego ciała mogą zostać odczytane jako przejaw wkroczenia w początkową fazę rytuału przejścia, fazę separacji. Pomimo iż bohaterce nie udaje się zrealizować swego zamierzenia, a więc nie potrafi ona wypreparować mentalnej ekstensji swego ",ja", przechodzi ona do kolejnego etapu omawianego rytuału, a wejście to na poziomie fabuły-sjużetu zostaje zespolone $\mathrm{z}$ wkroczeniem do sali, gdzie oczekuje na nią Łochmatow:

Наконец перед ними - массивная деревянная дверь с резьбой. Вверху Алёна увидела деревянную маску в виде человеческого лица с закрытыми глазами (I, 122-123).

Należy pamiętać, że znaczeniowe pole spotkania, do jakiego doszło pomiędzy bohaterami, odsłania także inny kontekst. Przejście przez drzwi nierozdzielnie wiąże się z przestąpieniem przez próg, które z kolei nasuwa myśl o przekroczeniu pewnej niewidzialnej granicy, symbolicznym wejściu w nowy etap życia. W wierzeniach słowiańskich próg odgrywał niezwykle istotną rolę: nie tylko wyznaczał granicę domostwa, lecz także rozdzielał

${ }^{4}$ Zapis tego słowa $\mathrm{w}$ danej formie za: M. J a k u b c z a k, Wyzwalanie się od Ja, [w:] tejże, Sens ja. Koncepcja podmiotu w filozofii indyjskiej (sankhja-joga), Kraków 2013, s. 192. 
świętą przestrzeń wewnątrz domu, od tego co na zewnątrz - chaosu ${ }^{5}$. Pełnił także funkcję sakralnej granicy, której przysługiwała szczególna moc $^{6}$, był miejscem styku dwóch światów (sacrum i profanum), a tym samym punktem granicznym, osobliwym wyznacznikiem nieciągłości przestrzeni ${ }^{7}$. Drzwi i próg w naturalny sposób związane były z ideą wejścia i wyjścia, której przypisuje się wysoki stopień semiotyczności ${ }^{8}$ Przekroczenie granicy domostwa czy też konkretnego pomieszczenia metaforycznie oznaczać również mogło rozpoczęcie nowego etapu, wkroczenie w nieznany obszar, i wydaje się, że właśnie $\mathrm{w}$ ten sposób należy odczytywać wejście bohaterki do sali. Wraz z pojawieniem się w pomieszczeniu Alona zaczyna bowiem odczuwać specyficzną aurę, jaką nacechowana jest wspomniana przestrzeń - $\mathrm{w}$ miejscu tym dominuje atmosfera wyjątkowości i imperialności. Uwagę bohaterki przykuwa fotel stylizowany na tron, na którego oparciu widnieje ten sam co wcześniej motyw wyrzeźbionej hebanowej maski:

на внушительной спинке [...] трона возвышался отнюдь не золотой орел, а вся та же маска: жутковатое из черного дерева лицо с закрытыми глазами (I, 123).

Osobliwe „koczowanie” tego przedmiotu („ta sama”, a nie „taka sama” maska) jednoznacznie wskazuje na konieczność bacznej analizy jego metaforyki, co podyktowane jest następującym pytaniem: dlaczego maska się przemieszcza i na co wskazuje wykonany przez nią ruch? Różnorodność kodów kulturowych (культурных смыслов), a także symboliczna nośność, jakimi nacechowana jest maska, bez wątpienia skutkują wielością możliwych interpretacji jej obecności $\mathrm{w}$ tekście powieści. Wydaje się, iż wbrew przyjętemu poglądowi o tym, iż jest ona symbolem fałszu, kłamstwa i oszczerstw, w Innym jej funkcja ulega rehabilitacji, jako że sam przedmiot może wskazywać na odsłanianie tego, co ukryte. Najbardziej rozpowszechnionym celem nałożenia maski jest ukrycie oblicza, a tym samym zamaskowanie pewnej prawdy, przywdzianie fałszywej pozy. Dualność, jaka cechuje ten przedmiot, związana jest $\mathrm{z}$ faktem, iż atrybut ten nie tylko naśladuje rzeczywistość (na przykład odwzorowuje kształt twarzy), ale także ją zniekształca, ukrywając to, co najistotniejsze. We współczesnym rozumieniu tego słowa pełni zatem funkcję osobliwego kamuflażu, jest kłamli-

${ }^{5}$ M. S u 1 i m a, Symboliczne przestrzenie domu, "Zeszyty Naukowe Politechniki Białostockiej. Architektura" 2007, nr 20, s. 89.

${ }^{6} \mathrm{G}$. van der L e e u w, Fenomenologia religii, Warszawa 1978, s. 350. Cyt za: ibidem.

${ }^{7}$ M. S u 1 i m a, Rola religii w kształtowaniu przestrzeni domu wiejskiego, "Zeszyty Naukowe Politechniki Białostockiej. Architektura" 2008, nr 21, s. 89.

${ }^{8}$ A.K. B a j b u r i n, W sprawie opisu struktury stowiańskiego rytuału budowniczego, „Konteksty” 1990, nr 3, s. 64. Cyt. za: Ibidem. 
wym wyrazem tego, czego $\mathrm{w}$ istocie nie ma. Tymczasem tak przyjęte postrzeganie tego przedmiotu jest rezultatem spowszednienia i zwietrzenia tego, co dawniej odnosiło się do sfery sacrum i stanowiło swego rodzaju ikonę 9 . Maska, wbrew podstawowemu polskiemu znaczeniu tego słowa, nie służyła do zasłaniała prawdy o człowieku, lecz przeciwnie - do jej odsłaniania ${ }^{10}$. Grecki źródłosłów pokazuje bowiem, iż jej pierwotnym celem było o d sło n i e n i e prawdy o człowieku, obnażenie jego prawdziwej natury, a z biegiem czasu słowa "prosopon" (maska) i „persona” (człowiek) zostały potraktowane jako określenia opisujące specyfikę natury człowieka ${ }^{11}$. Maska zawiera w sobie także charakterystyczny naddatek nacechowany symbolicznie, który jest na tyle silny, że zdaje się docierać do archetypowego obrazu człowieka12. Jej nieludzki charakter, np. zoomorficzny, najpełniej wyraża ukryty aspekt ,ja" - potwornego sobowtóra człowieka, który, będąc ucieleśnieniem pierwotnego chaosu, objawia człowiekowi dialektykę jego własnej natury ${ }^{13}$. To spotkanie z Innym „we mnie” jest dramaturgiczną osią wszelkich rytuałów inicjacyjnych, w których maska tak często odgrywa kluczową rolę. Podwójna modalność wyrażalności, tzn. reprezentowanie zarówno człowieka, jak i jego "dopełnienia”, którego posiadania podmiot może nawet nie być świadomy, czyniąc z maski znak przejścia, decyduje o jej trudnej do uchwycenia ambiwalencji. Maska zatem pośredniczy między światem ludzi i pierwotnym nieludzkim porzadkiem, staje się mediatorem ${ }^{14}$. Przedmiot, który widzi Alona przed wejściem do sali, przedstawia ludzką twarz z zamkniętymi oczami. Zdecydowana większość tego typu artefaktów, bez względu na charakter, w jakim zostanie użyta (np. do gry w teatrze, podczas karnawału czy też wszelkiego rodzaju rytuałów), posiada wycięte otwory na oczy, tak, aby noszące je osoby widziały, gdzie się znajdują. Wzrok jest jednym z tych zmysłów, który $\mathrm{w}$ przeważającym stopniu wpływa na poczucie orientacji w terenie. Pozbawienie kogoś możliwości obserwowania otaczającej przestrzeni zmusza do wyostrzenia innych zmysłów oraz wsłuchania się w swoje wnętrze. Warto

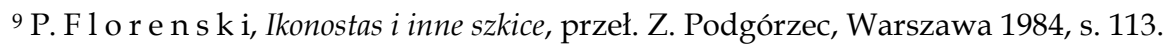

${ }_{10}$ M. D r w i ę g a, Dwie drogi wspótczesnych filozofów - Paul Ricoeur i Józef Tischner, „Znak” 2011, nr 669, [w:] źródło elektroniczne: http://www.miesiecznik.znak.com.pl/ 139/7/dwie-drogi-wspolczesnych-filozofow-paul-ricoeur-i-jozef-tischner-czesc-ii (17.07. 2014).

11 Z. K r u c z a 1 a k, Wybrane problemy z filozofii człowieka, „Monitor” 2011, [w:] źródło elektroniczne: http://www.monitorpl.com/monitorarticle/2011_11_10_Wybrane_ problemy_z_filozofii_czlowieka.qb (28.05.2015).

${ }_{12}$ M. Ż e r k o w s k i, Kultura maski, [w:] źródło elektroniczne: http://roverground.cz/ mealingua/kultura-maski/ (28.05.2015).

13 Ibidem.

14 Ibidem. 
również zaakcentować potencjał sprawczy, jakim nacechowany jest wspomniany artefakt. W praktyce archaicznej był on postrzegany jako dodatkowy kontur ciała, posiadający symboliczne znaczenie wyrażone na powierzchni i jednocześnie transformujące otaczającą rzeczywistość. Stanowił osobliwe „przedłużenie" człowieka, zwiększając jego cechy osobowościowe. Dzięki niemu człowiek miał szansę na przybranie zupełnie innego wizerunku - twarzy antagonisty czy też potwornego sobowtóra. Jednakże pod maską ciągle jeszcze skrywało się prawdziwe oblicze osoby ją przywdziewającej, toteż nie mogła być ona nacechowana niekontrolowanym potencjałem samosprawczości. Oczywiście nie da się zaprzeczyć, iż jako akcesorium niezwykle energetyczne posiada ona ogromną moc sprawczą i jest w stanie uruchomić w człowieku pewne cechy bądź zachowania, które nie są dla niego swoiste; $\mathrm{z}$ drugiej jednak strony okazuje się pomocna $\mathrm{w}$ procesie samopoznania, dzięki gwarantowanemu poczuciu anonimowości, uwalniającemu noszącą ją osobę od przestrzegania norm społecznych czy też etycznych. Tak więc nałożenie maski interpretować można $\mathrm{w}$ pewnych kontekstach nie tylko jako swego rodzaju próbę, na jaką wystawiona zostaje osoba ją nakładająca, lecz także jako jeden z czynników pełniących istotną rolę $\mathrm{w}$ procesie poznawania samego siebie.

Taką też symboliczną funkcję zdaje się pełnić wspomniany powyżej przedmiot w Innym. Obecność maski nad wejściem, gdzie będą się ważyć losy Alony, może symbolizować przekroczenie swego rodzaju granicy. Granicy, świadomie bądź nie, wytyczonej zarówno przez Łochmatowa, jak i narzeczoną Wadima. Trofim Borysycz „zaprosił” malarkę wiedziony swego rodzaju wewnętrznym impulsem - poczucie wspólnotowości i zaskakującej bliskości z nieznanym mu człowiekiem spowodowało, iż postanowił "otworzyć się" na artystkę, wyjawić jej swe plany odnośnie duchowego samorozwoju, a tym samym odrzucić na moment zainteresowaną jedynie materią pozę. Alona z kolei wchodząc do pokoju, nie tylko przekracza granice własnego strachu, lecz także własnych o g r a n i c z e ń, co znajduje potwierdzenie $\mathrm{w}$ dokonanej przez bohaterkę introspekcyjnej analizie podmiotowości. W tak zarysowanym kontekście maska może być postrzegana nie tylko jako niemy obserwator, ale i mediator pomocny w eksplorowaniu dopełnienia „ja”, co z kolei eksponuje dialogiczność natury bohaterów. Dany artefakt jest więc poniekąd materialnym reprezentantem rytuału inicjacyjnego, zmierzającego do odkrycia przez powieściowe postaci swego prawdziwego oblicza. Ponadto stanowi on swego rodzaju mechanizm obronny, samokonstruującą się strategię działań, wynikającą z chęci projekcji swego nieprawdziwego wizerunku lub zdobycia anonimowości, których celem jest ochrona naszego innego "Ja"; jest więc aktualizacją własnego wizerunku w konkretnym schemacie zachowań, a tym samym stanowi jeden ze sposobów zwiększenia samoświadomości jednostki, która poprzez stały 
namysł na własnym "Ja" (осмысливание) pozwala pokonać wewnętrzny „dualizm" i osiągnąć pełnię, ostateczną integrację ${ }^{15}$. W tak zarysowanej perspektywie maska umieszczona przed wejściem do sali, w której ma dojść do spotkania o fundamentalnym wręcz znaczeniu dla każdej ze stron, może nie tylko symbolizować dualizm bohaterów, dialogiczność ich natury. Staje się także zapowiedzią podejmowanego wysiłku zorientowanego na redefinicję swej podmiotowości, który będzie udziałem Alony, oraz dekonstrukcję, a następnie obnażenie swej prawdziwej natury w przypadku Łochmatowa. Jawi się ona zatem jako substancjalny reprezentant rozpoczęcia procesu duchowego przeobrażenia. Nie bez znaczenia jest również fakt, iż umieszczona jest ona nad drzwiami. Jej metaforyka zostaje znacząco zintensyfikowana za sprawą odwołań do nośności semiotycznej związanej $\mathrm{z}$ pojęciem progu i szerokim kontekstem samokonstruujących się ( $\mathrm{w}$ tak zaproponowanym ujęciu) konwergentnych odniesień na linii maska-próg.

Nie należy także zapominać o fakcie, iż maska „koczuje”: znad drzwi przemieszcza się na oparcie fotela, stylizowanego na tron, a ten przecież symbolizuje punkt oparcia $\mathrm{w}$ czasach ciągłych zmian ${ }^{16}$. W takiej perspektywie spotkanie tkwiących $\mathrm{w}$ stanie antropologicznej niepewności bohaterów urasta do rangi wydarzenia o charakterze fundamentalnym dla dalszego ich rozwoju. Co więcej, fakt, że hebanowy artefakt znajduje się na oparciu charakterystycznego fotela, świadczyć może również o tym, iż bohater w nim zasiadający odrzuca wszelkie pozory, zrywa tę maskę ${ }^{17}$, ukazując tym samym swą prawdziwą twarz rozmówcy. Taka interpretacja wydaje się zasadna, jeśli zważyć na to, iż bohaterka została "zaproszona" na rozmowę z Łochmatowem, ponieważ ten dostrzegł swe oblicze na namalowanym przez nią obrazie. Tak więc zabieg umieszczenia maski na oparciu fotela zorientowany jest na wyeksponowanie prawdziwego wnętrza postaci. Ponadto szeroki kontekst wykorzystania tego motywu pozwala przypuszczać, iż znajdująca się w sytuacji granicznej (jeśli przywołać określenie Karla Jaspersa) bohaterka, otwierając drzwi do sali, w której oczekuje na

15 О.Ю. О с ь м у х и н а, Маска, „Знание. Понимание. Умение”, Москва 2007, № 2, s. 226-228.

16 O.M. Ф р е й д е н б е p, Трон, [w:] źródło elektroniczne: http://ec-dejavu. $\mathrm{ru} / \mathrm{t} /$ Throne.html (28.05.2015).

17 Warto przypomnieć $\mathrm{w}$ tak zarysowanym kontekście jungowskie rozumienie roli Maski (Persony) w procesie indywiduacji - jest to odrzucenie archetypu reprezentującego rolę społeczną, którą gra człowiek uwikłany w skomplikowaną sieć konwenansów. Dopełnienie Persony Animą bądź Animusem stanowi ważny krok na drodze rozwoju psychicznego. Zob. J. P r o k o p i u k, C. G. Jung, czyli gnoza XX wieku, [w:] C.G. J u n g, Archetypy $i$ symbole, przeł. J. Prokopiuk, Warszawa 1993. Jeśli zatem odczytywać symbolikę maski umieszczonej na oparciu fotela jako próbę przezwyciężenia Persony, nasunie się analogia wskazująca na moment, w jakim znajduje się Łochmatow w trakcie wspomnianego powyżej procesu. 
nią nieznajomy, przekracza niewyartykułowane, aczkolwiek wyznaczone przez siebie granice. Jakkolwiek maska nie tworzy konkretnego wymiaru czasowego, jej zastosowanie ma na celu podkreślenie ważnego, uroczystego momentu, w jakim jest nakładana - w przypadku omawianego tekstu eksponuje osobliwy charakter spotkania, jego doniosłość. Zatem fakt, iż umieszczona jest nad wejściem do pomieszczenia, gdzie będą ważyć się losy malarki, a następnie wraz z bohaterką wkracza do pokoju (przypomnijmy, że to "ta sama”, a nie "taka sama” maska), wolno przyjąć jako symboliczną zapowiedź przybliżania do prawdy. Podjęcie relacji "twarzą w twarz", a tym samym ujawnienie swego prawdziwego oblicza - najczystszego przejawu formy ducha, jądra wyłuskanego z martwej skorupy, która krępowała jego zwoje ${ }^{18}$ - sprawi, iż Alona w trakcie (roz)mowy ${ }^{19}$, a także na fali wrażenia, jakie zrobi na niej wymiana zdań z Łochmatowem, podejmie próbę rekontekstualizacji swojego życia.

Wizyta u Łochmatowa staje się więc momentem przełomowym w samopostrzeganiu Alony. Nowa sytuacja, w jakiej bohaterka musi się odnaleźć, stanowi impuls dla głębokich przemyśleń o podłożu egzystencjalno-metafizycznym. Ponadto, zawarcie znajomości z Łochmatowem przyczynia się do redefinicji życia malarki. Wydarzenia, do jakich doszło w willi, spowodowały, że Alona nabrała życiowego dystansu i z większą samoświadomością percypowała otaczającą ją przestrzeń, a także procesy w niej zachodzące. Doceniła przede wszystkim wartość uczuć: wolności, której odzyskanie było dla niej jak ponowne narodziny („Где-то она чувствовала себя новорожденной" (I, 151)), i miłości, jaką darzył ją Wadim. Wychodząc z samochodu, który odwoził ją z willi Łochmatowa, malarka doznała euforycznego wręcz poczucia szczęścia. Stan ten stanowił przyczynek do wprowadzenia określonych zmian w jej życiu. Wydaje się, iż dojrzała ona emocjonalnie $-\mathrm{z}$ łatwością podjęła decyzję o zerwaniu $\mathrm{z}$ dotychczasowym stylem życia, doceniła wartość miłości, zaangażowania i oddania:

Я вчера позвонила ему и порвала с ним. Давно созрело. Но эта история послужила инициацией [...] (I, 158).

Spotkanie stanowiło zatem impuls do zmian w życiu bohaterki. $\mathrm{W}$ znacznym stopniu przyczyniło się do dekonstrukcji oraz redefinicji fundamentów jej podmiotowości, rewizji życiowych priorytetów, a także odegrało istotną rolę $\mathrm{w}$ procesie samopozna(wa)nia Alony. Zawarcie znajomości z Łochmatowem, w perspektywie całościowego odczytania utworu, można także postrzegać jako niezwykle ważny moment w życiu bohaterki

18 P. F l o r e n s k i, op. cit., s. 11.

19 Zapis w tej postaci odsyła do filozofii dialogu Levinasa. Zob. E. L e v i n a s, Separacja i roz(mowa), [w:] tegoż, Całość i nieskończoność. Esej o zewnętrzności, przeł. M. Kowalska, Warszawa 1998, s. 44-82. 
- moment, który umożliwił jej rozpoczęcie procesu mentalnego przeobrażenia i duchowego wzrastania. Spotkanie z bandytą urasta zatem do rangi wydarzenia o charakterze epifanijnym - $\mathrm{w}$ ślad za rozumieniem tego pojęcia w kluczu filozoficzno-antropologicznej ontologii Michaiła Bachtina, gdzie stanowi ono wyraz egzystencjalnej koncepcji indywidualnego podmiotu, który dopiero „staje się" w relacjach z innymi ludźmi ${ }^{20}$.

\section{Bibliografia}

B a j b u r i n A.K., W sprawie opisu struktury stowiańskiego rytuału budowniczego, „Konteksty" 1990, nr 3, s. 64.

D r w i ę g a M., Dwie drogi wspótczesnych filozofów - Paul Ricoeur i Józef Tischner, "Znak" 2011, nr 669, [w:] źródło elektroniczne: http://www.miesiecznik.znak.com.pl/139/7 /dwie-drogi-wspolczesnych-filozofow-paul-ricoeur-i-jozef-tischner-czesc-ii (17.07.2014).

F l o r e n s k i P., Ikonostas i inne szkice, przeł. Z. Podgórzec, Warszawa 1984.

J a k u b c z a k M., Wyzwalanie się od Ja, [w:] tejże, Sens ja. Koncepcja podmiotu w filozofii indyjskiej (sankhja-joga), Kraków 2013, s. 192.

L e e u w van der G., Fenomenologia religii, Warszawa 1978.

L e s s a W.A., V o g t E.Z., Reader in Comparative Religion: An Anthropological Approach (4th Edition), New York 1979.

L e v i n a s E., Całość i nieskończoność. Esej o zewnętrzności, przeł. M. Kowalska, Warszawa 1998.

L e v i n a s E., Separacja i roz(mowa), [w:] tegoż, Całość i nieskończoność. Esej o zewnętrzności, przeł. M. Kowalska, Warszawa 1998, s. 44-82.

P r o k o p i u k J., C.G. Jung, czyli gnoza XX wieku, [w:] C.G. J u n g, Archetypy i symbole, przeł. J. Prokopiuk, Warszawa 1993.

S u 1 i m a M., Rola religii w ksztattowaniu przestrzeni domu wiejskiego, "Zeszyty Naukowe Politechniki Białostockiej. Architektura" 2008, nr 21, s. 89.

S u 1 i m a M., Symboliczne przestrzenie domu, "Zeszyty Naukowe Politechniki Białostockiej. Architektura" 2007, nr 20, s. 89.

T u r n e r V., Betwixt and between: The liminal period in "rites of passage", [w:] W.A. L e s s a, E.Z. V o g t, Reader in Comparative Religion: An Anthropological Approach (4th Edition), New York 1979, s. 234-243.

Ż e r k o w s k i M., Kultura maski, [w:] źródło elektroniczne: http://roverground. cz/mealingua/kultura-maski/ (28.05.2015).

${ }^{20}$ Rosyjski mśliciel wykorzystuje nieprzetłumaczalną na język polski grę słów, gdzie wyraz событue tłumaczony jest jako „wydarzenie”, natomiast rozdzielenie go dywizem co-быmue powoduje zmianę znaczenia na „współistnienie”, „współbytność”, co eksponuje fundamentalną rolę dialogu i spotkania z Innym w procesie kształtowania osobowości jednostki (становление личности). Zob. М.М. Б а х т и н, Автор и герой В эстетической деятельности. Проблема автора, [w:] źródło elektroniczne: http://mmbakhtin. narod.ru/probl.html (31.05.2015). 
Б а х т и н М.М., Автор и герой $b$ эстетической деятельности. Проблема автора, [w:] źródło elektroniczne: http://mmbakhtin.narod.ru/probl.html (31.05.2015).

М а м л е е в Ю.В., Другой, Щелково 2007.

О с ь м у х и н а О.Ю., Маска, „Знание. Понимание. Умение”, Москва 2007, № 2 , s. $226-228$.

П о н о м а р е в Ф.А., Катарсические эффекты в творчестве Юрия Мамлеева, [w:] źródło elektroniczne: http://www.google.ru/url?sa=t\&rct=j\&q=\&esrc=s\&frm=1\& source=web\&cd=1\&ved=0CCkQFjAA\&url=http $\% 3 \mathrm{~A} \% 2 \mathrm{~F} \% 2 \mathrm{Fzar}-$ literature.ucoz.ru $\%$ 2Fdidaktika_1\%2Fkatarsicheskie_ehffekty_v_tvorchestve_jurija_mamle.docx\&ei=E1 bFUqWfNoHXtAbZ6oGoDg\&usg=AFQjCNFkr1mquVZJce4pr0lhyF_Np0wqpA\&bv $\mathrm{m}=$ bv.58187178,d.Yms\&cad=rjt (14.10.2013). 